\title{
PENYAKIT KULIT PADA PEKERJA PENYAMAKAN KULIT DI DESA MOJOPURNO KECAMATAN NGARIBOYO KABUPATEN MAGETAN TAHUN 2015
}

Lathiefah Ekawati, NurHaidah, Marlik

\begin{abstract}
Leather tanning is an industry that processes raw hides into finished leather. This process uses chromium. Chromium will be in contact with workers' skin. The purpose of this study is to describe skin disease in tanning workers in Mojopurno Village, Sub District of Ngariboyo, Magetan 2015.

This is a descriptive study conducted by illustrating skin diseases in tanning workers. The description of skin diseases in the study includes characteristicsof skin disease, knowledge, attitudes and actions of workers as well as environmental factors. The population of this study was tanning workers of Mojopurno Village, Magetan.

The result shows that there were 24 out of 103 workers who suffered from skin problems. Most of the sufferers were $41-50$ years of $41.6 \%$. Exposure duration with Chromium was $\geq 8$ hours / day of $95.8 \%$ with doses of Chromium of $80 \mathrm{mcg} / \mathrm{m3} .12 .5 \%$ of the sufferers possessed history of allergy to chemicals. $54.2 \%$ Suffererspossessed fairly good knowledge on occupational skin diseases. 100\% sufferers performed good attitude and $66.7 \%$ sufferers performed good action. Work environment (temperature, humidity and ventilation) in the leather tanning of Mojopurno Village, Magetan have qualified.

Home Industry owners are advised to provide education on health and safety at work particularly onoccupational disease, provideand enforce policies in the use the equipment. Workers are expected to always usecomplete Personal Protective Equipment (PPE). Community around Leather tanning Home industry should submit suggestions and complaints to the owner of Home Industry.
\end{abstract}

Keywords : Leather Tanning, Skin Diseases

\section{PENDAHULUAN}

Penyakit kulit merupakan penyakit yang umum diderita oleh masyarakat. Faktorfaktor yang menyebabkan timbulnya penyakit kulit antara lain faktor host (penjamu) seperti umur, lama paparan dan riwayat alergi, faktor agent (penyebab penyakit) seperti paparan bahan kimia dan faktor environment (lingkungan) seperti suhu tempat kerja dan keberadaan ventilasi di tempat kerja, selain itu penyakit kulit bisa juga didapat sewaktu melakukan pekerjaan yang dinamakan penyakit kulit akibat kerja. Agen sebagai penyebab penyakit kulit tersebut antara lain berupa agen-agen fisik, kimia maupun biologis. Kebanyakan agen tersebut terdapat dalam pekerjaan industri. Salah satu diantaranya adalah industri penyamakan kulit yang dalam proses produksinyamenggunakanbahankimiaKromiu $\mathrm{m}$ terutama yang paling umum adalah fero kromit $\left(\mathrm{FeCr}_{2} \mathrm{O}_{3}\right)$. Kromium yang banyak digunakan pada industri penyamakan kulit adalah Kromium yang dilarutkan dalam air. Kromium akan kontak dengan pekerja Industri Penyamakan Kulit antara lain melalui kontak dengan kulit atau dengan cara penghirupan dalam bentuk gas atau uap yang dapat menyebabkan gangguan kesehatan pada pekerja. Pemaparan bahan kimia utamanya terhadap kulit dapat mengakibatkan gangguan berupa alergi dan iritasi dengan gejala-gejala gatal, kulit kering, kemerah-merahan, dan pecah-pecah. Data puskesmas Kecamatan Ngariboyo Kabupaten Magetan (2013) penyakit kulit merupakan penyakit nomer 6 setelah penyakit darah tinggi primer, infeksi akut saluran pernafasan, penyakit pada sistem otot dan jaringan pengikat, gastritis dan common cold, dengan penderita sebanyak 2.299 orang. Survei pendahuluan dilakukan di home industri penyamakan kulit desa Mojopurno, Magetan pada 5 home industri dengan jumlah responden 25 pekerja, didapatkan sebanyak 13 pekerja (52\%) mengalami gejala-gejala penyakit kulit. Utamanya mereka mengalami gejala-gejala berupa gatal-gatal, kulit kering, kemerahmerahan serta pecah-pecah pada bagian lengan dan jari-jari tangan. Gejala-gejala tersebut umumnya dialami oleh penderita penyakit kulit yang disebabkan kontak bahan kimia Kromium.

Perumusan masalah adalah bagaimana gambaran penyakit kulit pada pekerja penyamakan kulit Desa Mojopurno, Magetan. 


\section{TUJUAN}

Mengetahui gambaran penyakit kulit pada pekerja penyamakan kulit di Home Industri Penyamakan Kulit Desa Mojopurno Kecamatan Ngariboyo Kabupaten Magetan tahun 2015.

\section{METODE PENELITIAN}

Jenis Penelitian ini termasuk deskriptif dengan metode survey dimana penelitian ini menggambarkan penyakit kulit pada sekelompok pekerja penyamakan kulit di Desa Mojopurno, Magetan. Unit penelitian ini adalah seluruh pekerja di 10 Home Industri penyamkan kulit Desa Mojopurno, Magetan sebanyak 103 orang dengan responden pekerja yang mengalami gejala gatal-gatal, kulit kering, kemerah-merahan dan pecah- pecah pada bagian lengan dan jari-jari tangan yang terdiagnosa penyakit kulit sebesar 24 orang. Variabel bebasnya adalah karakteristik penderita (umur, lama paparan, dan riwayat alergi), pengetahuan pekerja, sikap pekerja, tindakan pekerja dan factor lingkungan (suhu, kelembaban, dan keberadaan ventilasi). Analisis data yang digunakan adalah analisis data deskriptif.

\section{HASIL PENELITIAN DAN PEMBAHASAN Karakteristik Penderita}

Pekerja yang mengalami penyakit kulit adalah 24 orang $(23,3 \%)$ dari 103 pekerja di 10 Home Industri penyamakan kulit Desa Mojopurno, Magetan. Karakteristik penderita adalah sebagai berikut:

\section{Umur}

Tabel 1.

Distribusi Pekerja Home Industri Penyamkan Kulit Berdasarkan Umur Desa Mojopurno Kecamatan Ngariboyo Kabupaten Magetan Tahun 2015

\begin{tabular}{|c|l|c|c|}
\hline No. & \multicolumn{1}{|c|}{ Umur Pekerja } & $\begin{array}{c}\text { Jumlah } \\
\text { (orang) }\end{array}$ & $\begin{array}{c}\text { Prosentase } \\
(\%)\end{array}$ \\
\hline 1. & $<30$ Tahun & 7 & 29,2 \\
\hline 2. & $30-40$ Tahun & 7 & 29,2 \\
\hline 3. & $41-50$ Tahun & 10 & 41,6 \\
\hline 4. & $>50$ Tahun & 0 & 0 \\
\hline \multicolumn{2}{|r|}{ Total } & 24 & 100 \\
\hline
\end{tabular}

Tabel 1, menunjukkan bahwa sebagian besar pekerja penyamakan kulit yang mengalami sakit kulit berumur $41-50$ tahun sebesar $41,6 \%$ (10 orang). Pada kelompok umur $41-50$ tahun memiliki kerentanan lebih tinggi terhadap bahan kimia.

1. Lama Paparan

Lama paparan Kromium pada penderita penyakit kulit dalam waktu $\geq 8$ jam/hari sebesar 95,8\% (23 orang). Paparan tersebut terjadi 2 kali dalam sebulan untuk Home Industri kecil sedangkan untuk Home Industri besar dapat terjadi 4 kali dalam sebulan.

2. Riwayat Alergi

Dari 24 penderita penyakit kulit sebesar 12,5\% (3 orang) mempunyai riwayat alergi terhadap bahan kimia.

\section{Pengetahuan Penderita}

Tabel 2.

Distribusi Pekerja Berdasarkan Tingkat Pengetahuan Di Home Industri Penyamakan Kulit Desa Mojopurno Kecamatan Ngariboyo Kabupaten Magetantahun 2015

\begin{tabular}{|c|l|c|c|}
\hline No. & \multicolumn{1}{|c|}{ Tingkat Pengetahuan } & $\begin{array}{c}\text { Jumlah } \\
\text { (orang) }\end{array}$ & $\begin{array}{c}\text { Prosentase } \\
(\%)\end{array}$ \\
\hline 1. & Baik & 11 & 45,8 \\
\hline 2. & Cukup & 13 & 54,2 \\
\hline 3. & Kurang & 0 & 0 \\
\hline \multicolumn{2}{r|}{ Total } & 24 & 100 \\
\hline
\end{tabular}

Tabel 2, menunjukkan bahwa sebagian besar tingkat pengetahuan pekerja penyamakan kulit Desa Mojopurno Kecamatan Ngariboyo Kabupaten Magetan tentang penyakit kulit akibat kerja adalah cukup baik sebesar $54,2 \%$ (13 orang). Pengetahuan penderita penyakit kulit adalah cukup baik. Pengetahuan tentang pengertian penyakit kulit akibat kerja, penyebab penyakit kulit dan akibat bahan kimia pada kesehatan kurang diketahui oleh penderita penyakit kulit di Home Industri penyamakan kulit Desa Mojopurno, Magetan. 


\section{SikapPenderita}

Tabel 3.

Distribusi Pekerja Berdasarkan Sikap Di Home Industri Penyamakan Kulit Desa Mojopurno Kecamatan Ngariboyo Kabupaten Magetan Tahun 2015

\begin{tabular}{|c|l|c|c|}
\hline No. & \multicolumn{1}{|c|}{ Sikap } & $\begin{array}{c}\text { Jumlah } \\
\text { (orang) }\end{array}$ & Prosentase (\%) \\
\hline 1. & Baik & 24 & 100 \\
\hline 2. & Cukup & 0 & 0 \\
\hline 3. & Kurang & 0 & 0 \\
\hline \multicolumn{2}{|c|}{ Total } & 24 & 100 \\
\hline
\end{tabular}

Tabel 3, menunjukkan bahwa sikap pekerja penyamakan kulit Desa Mojopurno Kecamatan Ngariboyo Kabupaten Magetan yang mengalami sakit kulit adalah baik sebesar $100 \%$ (24 orang). Sikap penderita penyakit kulit adalah baik.

\section{TindakanPenderita}

Tabel 4.

Distribusi Pekerja Berdasarkan Tindakan Di Home Industri Penyamakan Kulit Desa Mojopurno Kecamatan Ngariboyo Kabupaten Magetan Tahun 2015

\begin{tabular}{|c|l|c|c|}
\hline No. & \multicolumn{1}{|c|}{ Tindakan } & $\begin{array}{c}\text { Jumlah } \\
\text { (orang) }\end{array}$ & Prosentase (\%) \\
\hline 1. & Baik & 16 & 66,7 \\
\hline 2. & Cukup & 8 & 33,3 \\
\hline 3. & Kurang Total & - & - \\
\hline \multicolumn{1}{|c|}{ Tol } & 24 & 100 \\
\hline
\end{tabular}

Tabel 4, menunjukkan bahwa sebagian besar tindakan pekerja penyamakan kulit Desa Mojopurno Kecamatan Ngariboyo Kabupaten Magetan yang mengalami sakit kulit adalah baik sebesar 66,7\% (16 orang) dalam pencegahan dan penanggulangan penyakit kulit akibat kerja.

\section{FaktorLingkungan}

Setelah dilakukan pengukuran, suhu tempat kerja di 10 Home Industri penyamakan kulit Desa Mojopurno Kecamatan Ngariboyo Kabupaten Magetan antara $26^{\circ} \mathrm{C}-28^{\circ} \mathrm{C}$ telah memenuhi syarat berdasarkan Kepmenkes No 1405/MENKES/SK/X/2002 tentang persyaratan lingkungan kerja perkantoran dan industri yaitu $\leq 28^{\circ} \mathrm{C}$. Kelembaban lingkungan kerja terukur 30\% - 40\% telah memenuhi persyaratan berdasarkan Kepmenkes No 1405/MENKES/SK/X/2002 tentang persyaratan lingkungan kerja perkantoran dan industry yaitu $\leq 60 \%$. Untuk keberadaan ventilasi, 10 unit Home Industri penyamakan kulit telah memiliki ventilasi.

\section{KESIMPULAN}

1. Pekerja yang mengalami penyakit kulit sebesar 23,3\% (24 orang). Pekerja mengalami gatal-gatal, kemerah-merahan, kulit kering dan pecah-pecah pada bagian lengan dan jari-jari tangan termasuk jenis dermatosis kontak toksik.

2. Sebagian besar pekerja yang mengalami sakit kulit berumur 41-50 tahun sebesar $41,6 \%$ (10 orang).

3. Sebagian besar lama paparan penderita dengan Kromium $\geq 8$ jam/hari sebesar $95,8 \%$ (23 orang).
4. $12,5 \%$ (3 orang) penderita memiliki riwayat alergi terhadap bahan kimia.

5. Tingkat pengetahuan penderita penyakit kulit sebagian besar adalah cukup baik sebesar 54,2\% (13 orang).

6. Sebagian besar penderita penyakit kulit memiliki sikap yang baik dalam pencegahan dan penanggulangan penyakit akibat kerja sebesar $100 \%$ (24 orang).

7. Sebagian besar penderita penyakit kulit memiliki tindakan yang baik dalam pencegahan dan penanggulangan penyakit akibat kerja sebesar $66,7 \%$ (16 orang).

8. Faktor lingkungan kerja (suhu, kelembaban dan ventilasi) di lingkungan kerja penyamakan kulit Desa Mojopurno Kecamatan Ngariboyo Kabupaten Magetan $100 \%$ memenuhi syarat.

\section{SARAN}

1. Pemilik Home industri penyamakan kulit diharapkan memberikan penyuluhan tentang kesehatan dan keselamatan kerja khususnya tentang penyakit akibat kerja, menyediakan Alat Pelindung Diri (APD) yang lengkap seperti sarung tangan, pakaian panjang dan rim pelindung, serta memberlakukan kebijakan dalam 
penggunaan Alat Pelindung Diri (APD) yang lengkap.

2. Pekerja Home Industri penyamakan kulit sebaiknya meningkatkan pengetahuan tentang penyakit kulit akibat kerjadan melengkapi dirinya dengan menggunakan Alat Pelindung Diri (APD) seperti menggunakan sarung tangan, pakaian panjang dan krim pelindung untuk menurunkan potensi terjadinya penyakit kulit akibat kerja.

3. Masyarakat sekitar Home Industri penyamakan kulit sebaiknya menyampaikan saran dan keluhan kepada pemilik Home Industri penyamakan kulit untuk meningkatkan kenyamanan lingkungan sekitar Home Industri.

\section{DAFTAR PUSTAKA}

Achmad, Purwadi, 2011. Buku Petunjuk Teknis Tentang Beam House Operation Kulit Sapi Dari Wet Salting Untuk Keperluan Atasan Sepatu. Yogyakarta: Direktorat Jenderal Industri Logam Mesin Tekstil dan Aneka.

Badan Pemberdayaan Masyarakat dan Pemerintahan Desa, 2014. Profil Desa Mojopurno Kecamatan Ngariboyo Tahun 2014. Magetan: Desa Mojopurno.
Baktiansyah, A, 2010. Penyakit Akibat Kerja. Jakarta: PSPD FKK UMJ Press.

Bustan, 2010. Pengantar Epidemiologi. Jakarta: Rineka Cipta.

Cahyono, Achadi Budi, 2010. Keselamatan Kerja Bahan Kimia di Industri. Yogyakarta: Gadjah Mada University Press.

Notoatmodjo, Soekidjo, 2010. Metodologi Penelitian Kesehatan. Jakarta : Rineka Cipta.

Notoatmodjo, Soekidjo, 2012. Promosi Kesehatan dan Perilaku Kesehatan. Jakarta : Rineka Cipta.

Puskesmas Ngariboyo, 2013. Profil Puskesmas Ngariboyo. Magetan: Puskesmas Ngariboyo.

Sastiono, dkk, 2010. Efek Toksik Logam. Yogyakarta: CV. Andi Offset.

Siregar. 2013. Saripati Penyakit Kulit. Jakarta: EGC

Sugiono, 2012. Metode Penelitian Kuantitatif, Kualitatif dan $R \& D$. Bandung: Alfabeta.

Suma'mur, 2011. Higiene Perusahaan dan Kesehatan Kerja (HIPERKES). Jakarta: Sagung Seto.

UPT Industri Kulit dan Produk Kulit, 2010. Profil Industri Kulit dan Produk Kulit Magetan. Magetan: UPT Industri Kulit dan Produk Kulit. 